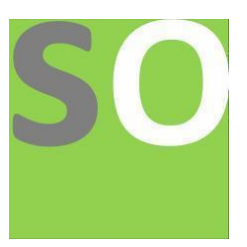

Article title: Navigating the Prevailing Challenges of the Nigerian Power Sector

Authors: Mustefa Jibril[1], Mustefa Jibril[2]

Affiliations: Hassan II University Casablanca,[1], Dire Dawa University, Dire Dawa, Ethiopia[2]

Orcid ids: 0000-0002-3165-2410[2]

Contact e-mail: mustefazinet1981@gmail.com

License information: This work has been published open access under Creative Commons Attribution License http://creativecommons.org/licenses/by/4.0/, which permits unrestricted use, distribution, and reproduction in any medium, provided the original work is properly cited. Conditions, terms of use and publishing policy can be found at https://www.scienceopen.com/.

Preprint statement: This article is a preprint and has not been peer-reviewed, under consideration and submitted to ScienceOpen Preprints for open peer review.

DOI: 10.14293/S2199-1006.1.SOR-.PPBARRU.v1

Preprint first posted online: 28 December 2021

Keywords: GENCOs, TCN, NCC, DISCOs, NBET, NERC 


\title{
Navigating the Prevailing Challenges of the Nigerian Power Sector
}

\author{
Eric Akpoviroro OBAR \\ Laboratory of Complex Cyber Physical Systems ENSAM, \\ Hassan II University Casablanca, Morocco akposobar@yahoo.com \\ Mustefa Jibril Taha \\ Industrial Control Engineering \\ Dire Dawa University, Dire Dawa, Ethiopia, Mustefa.jibril@ddu.edu.et
}

\begin{abstract}
The entire value chain of the Nigerian power sector (the production, transmission and distribution sector) is bedeviled with numerous challenges. Challenges that hamper and make the seventh sustainable development goal only a mirage.

This paper aims to take a panoramic view of the Nigerian power architecture, outlining the challenges of the various stakeholders (The Generation Companies, The Transmission Company of Nigeria, The National Control Center, The Distribution Companies, The Nigerian Bulk Electricity Trading Plc, The Nigerian Electricity Regulatory Commission, The Gas producers, The Nigerian Gas Company and the consumers) with the goal of providing a roadmap of solutions; solutions to light up the African largest economy and invariably guarantee her socio-economic development.
\end{abstract}

Keywords-GENCOs, TCN, NCC, DISCOs, NBET, NERC

\section{INTRODUCTION}

The Nigerian power sector post privatization is made up of 30 Generation companies (GENCOs), the Transmission company of Nigeria (TCN), 11 Distribution Companies (DISCOs), the National Control Center (NCC), the Nigerian Bulk Electricity Trading Plc (NBET) and the National Electricity Regulatory Commission (NERC).

With a peak transmission of 5801.60MW[1] for a population of 202 million[2] and the resort to diesel/gasoline generators by Nigerians for captive generation, these relevant and key stakeholders have fallen short of their duty to provide reliable, quality and affordable power supply to the Nigerian Nation.

We would begin by defining the relationship and interactions between the different stakeholders (GENCOs, TCN, NCC, DISCOs, NBET, NERC and the consumers) of the Nigerian power sector. We would outline the prevailing challenges of the different stakeholders based on data gotten from field visit of the entire value chain of the Nigerian power sector and finally propose a roadmap of solutions to light the African largest economy.

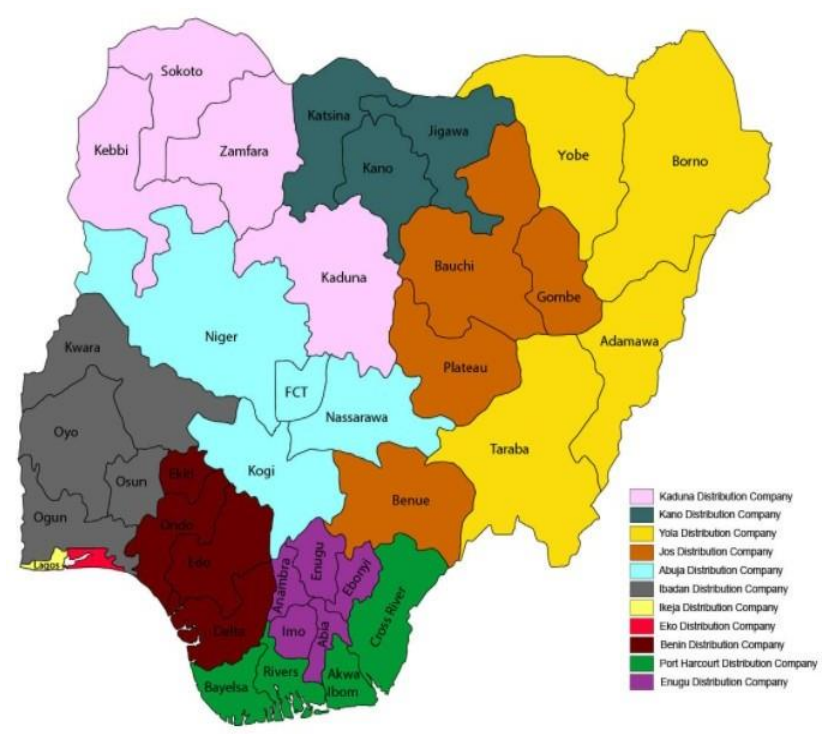

Figure 1: The 11 Distribution Companies[3]

\section{RELATIONSHIP AND INTERACTIONS BETWEEN THE DIFFERENT STAKEHOLDERS IN THE NIGERIAN POWER SECTOR}

The unidirectional and central paradigm of the national grid depends on the GENCOs for the production of electricity, TCN for the transmission of electricity (with the National Control Centre NCC, responsible for all TCN Grid Operations, Monitoring and Control within the Transmission network) and the DISCOs for the distribution of electricity. NBET which can be defined as the administrator and manager of the electricity pool (in the Nigerian electricity supply industry NESI) is tasked with purchasing electricity from the GENCOs, through Power Purchase Agreements (PPAs) and selling to the DISCOs through Vesting Contracts[4]. The Nigerian Electricity Regulatory Commission NERC is tasked with economic and technical regulation of the Nigerian Electricity Supply Industry. NERC also has the responsibility among others to license operators, determine operating standards and codes, 
set cost reflective industry tariffs and to establish customer rights and obligations[5]. We also have the gas producers and the Nigerian gas company (NGC) who produce and transport natural gas to the GENCOs with thermal generating units.

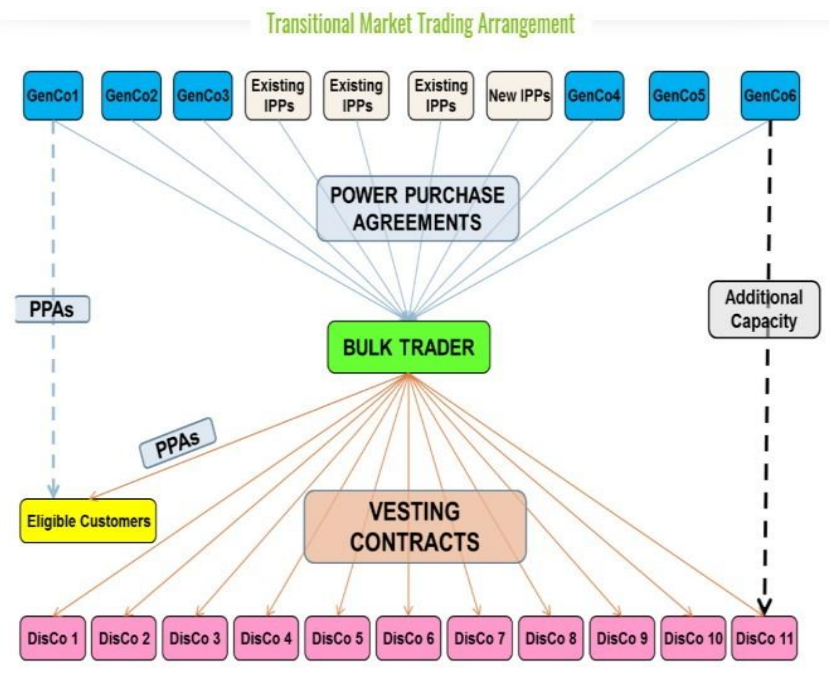

Figure 2: Transitional Market Trading Arrangement[4]

\section{RESEARCH METHODOLOGY}

This research began with literature survey on the existing challenges of the Nigerian Power Sector. After which came the need for industrial visits and consultations with major stakeholders of the electricity value chain(Gas Producers, NGC, GENCOs, TCN, DISCOs \& Consumers) to get primary and secondary data. The approach was a mix between the collection of qualitative and quantitative data for the Nigerian Power Sector.

The daily operational report of the Transmission Company of Nigerian for Monday 19/07/2021 was used to get the pulse of the Nigerian Electricity Supply Industry as regards National Statistics on the Electricity Generation Profile. This report also shows the system collapse update, the average generation for each power station, the system spinning reserve, the un-utilized generation due to gas constraints and low load demand by the DISCOs.

We also got valuable information from our interaction with workers at the different levels of the electricity value chain. All of these helped us appreciate, analyse and propose solutions to the numerous challenges of the Nigerian Power Sector.

\section{RESEARCH METHODOLOGY}

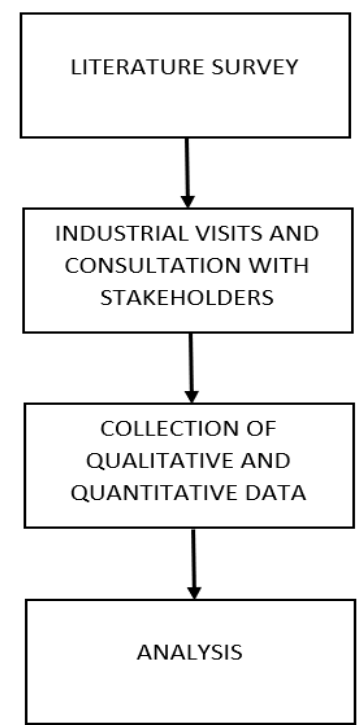

Figure 3: Research methodology

\section{RESULTS AND DISCUSSIONS}

Thanks to our research methodology we are able to enumerate the problems and solutions as regards the stakeholders of the electricity value chain. These challenges can be classified into the following categories:

- Challenges as regards the Gas producers \& Transporter (NGC)

- Challenges as regards the GENCOs

- Challenges as regards TCN

- Challenges as regards the DISCOs

- Challenges as regards the politics and policies of the power sector.

A. Challenges as regards the Gas producers \& Transporter $(N G C)$

- The willful vandalization of gas pipelines

- Inadequate supply of gas to the GENCOs[6]

- Low gas pressure[7]

- $\quad$ Maintenance of gas pipelines(Pigging etc)[7]

- The delivery of off-spec gas to the GENCOs

- The late payment for gas supplied to the GENCOs

- Inadequate investments in the gas sector

- Gas flaring which leads to economic losses and environmental degradation[8] 


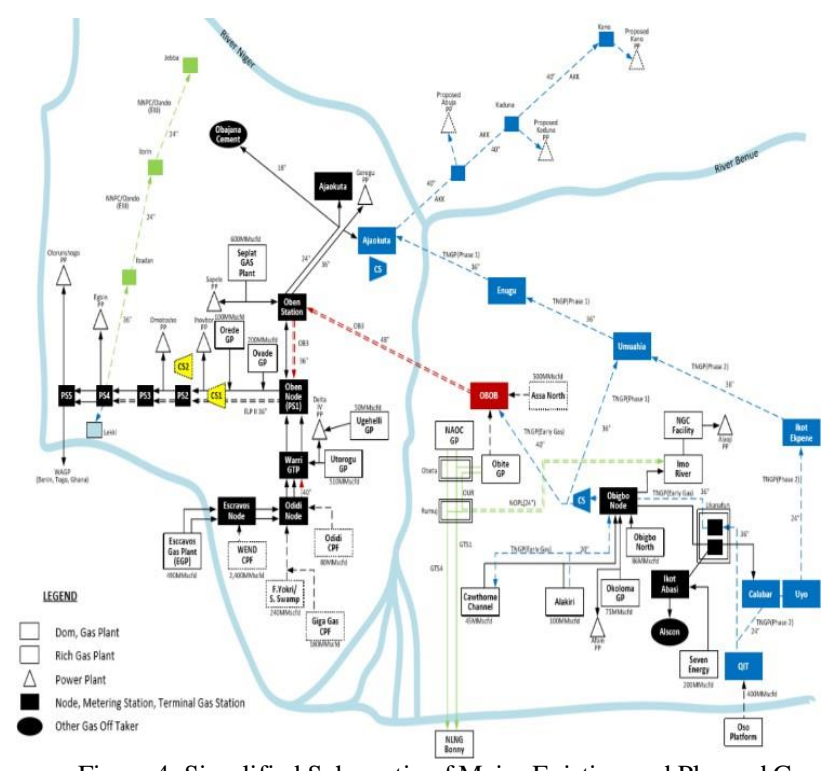

Figure 4: Simplified Schematic of Major Existing and Planned Gas Infrastructure

\section{B. Challenges as regards the GENCOs}

- Dips in electricity generation due to gas constraints caused either by the vandalization of pipelines, the maintenance of gas facilities, the supply of off-spec gas or the nonpayment of gas producers \& NGC (the gas transporter).

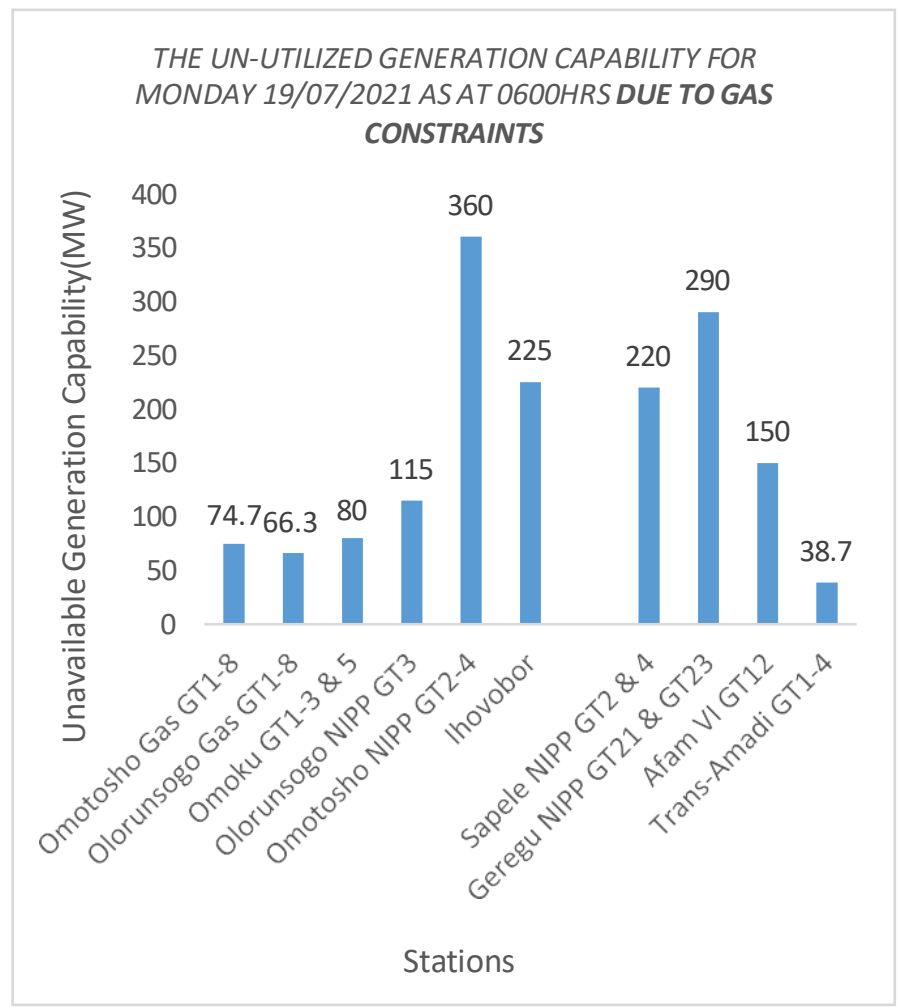

Figure 3: The un-utilized generation capability for Monday 19/07/2021 as at 0600hrs due to gas constraints[9]
- Forced reduction of the production capacity of the GENCOs by the National Control Center NCC due to the limitations of the National grid or load rejection by the DISCOs

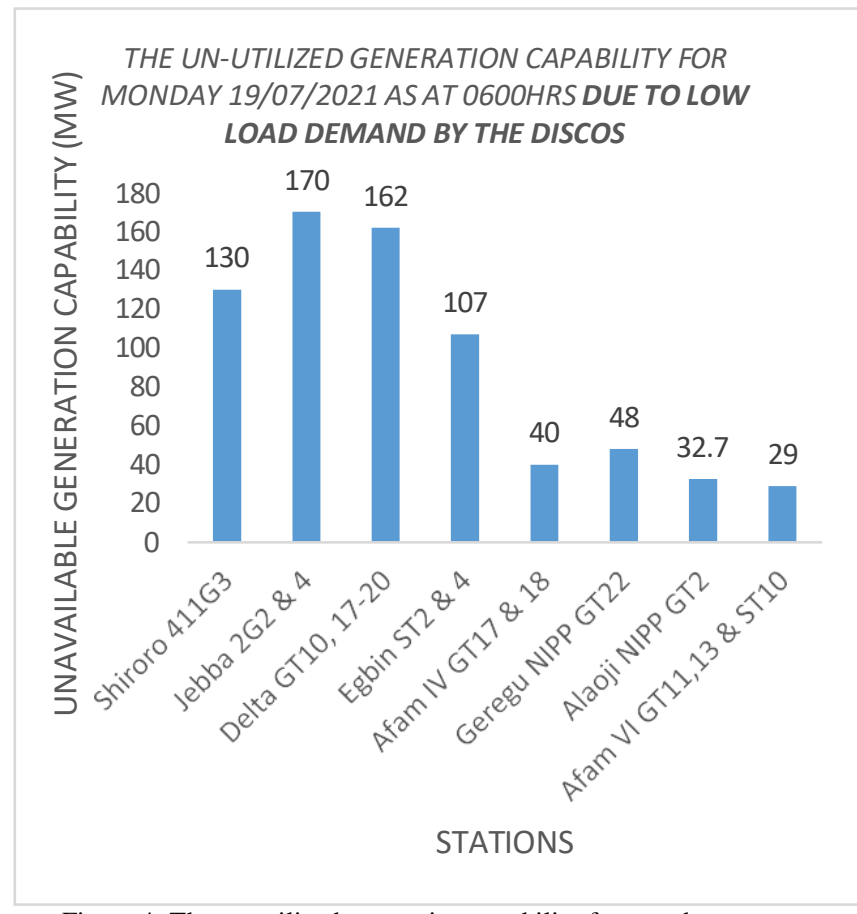

Figure 4: The un-utilized generation capability for monday $19 / 07 / 2021$ as at $0600 \mathrm{hrs}$ due to low load demand by the discos[9]

- Reluctance of the GENCOs to invest and increase their available capacity due to the limitations of the National Grid and the weak distribution networks

- Late payment of GENCOs by NBET due to late payment of debt owed by the DISCOs

- The practice of reactive maintenance, breakdown maintenance or run to failure maintenance of generating units by some GENCOs in order to bill NBET and "maximize profit"

- Dilapidated and obsolete plants in some power stations

- Seasonal constraints which affect the water level at hydropower plants[10]

\section{Challenges as regards TCN}

- The inability of TCN to wheel the available capacity of the GENCOs

- Inadequate grid coverage of Nigeria as a result of insufficient investments on transmission lines

- High Transmission losses (47\%-11\%)[11]

- Harassment and sometimes kidnapping (by locals) of TCN officials who patrol the transmission lines during intervention or inspection schedules 
- Terrain and vegetation challenges as transmission line routes go through swamps and forests with very fast regrowth

- Earth faults as a result of vegetation challenges which sometimes cascade into system collapse

- Willful vandalization of transmission towers

- The use of vehicles to patrol transmission lines that go through swamps and thick forests instead of surveillance helicopters

- Lack of stringing equipments for transmission lines

- Frequency rise and over voltages as a result of load rejection by the DISCOs

- Partial and total grid outage

\section{System Collapse Update from 01 January 2010- 20 July 2021}

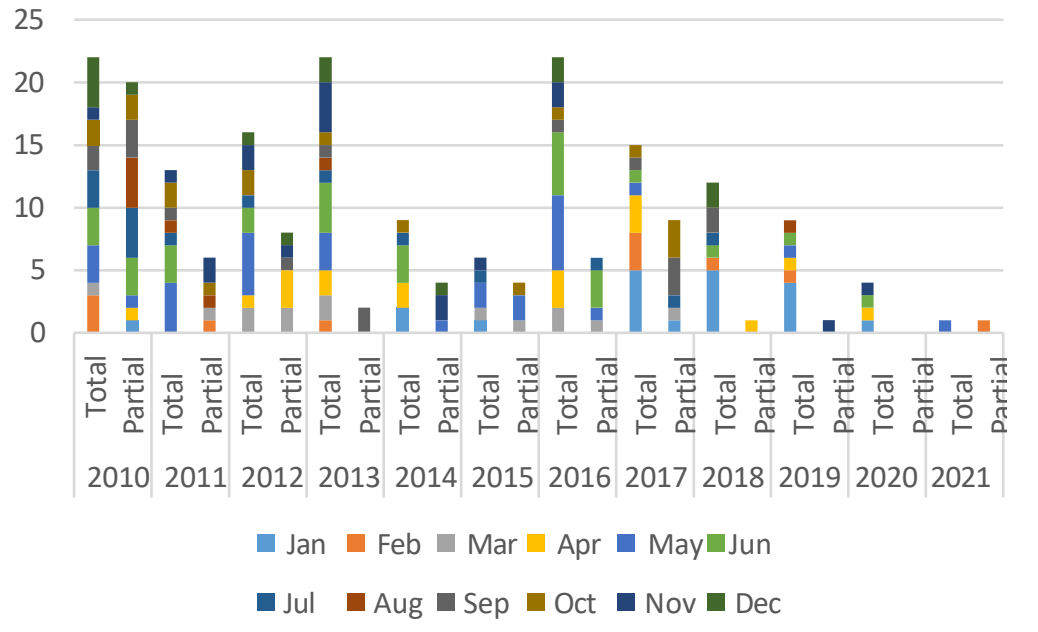

Figure 5: System Collapse Update from 01 January 2010- 20 July 2021

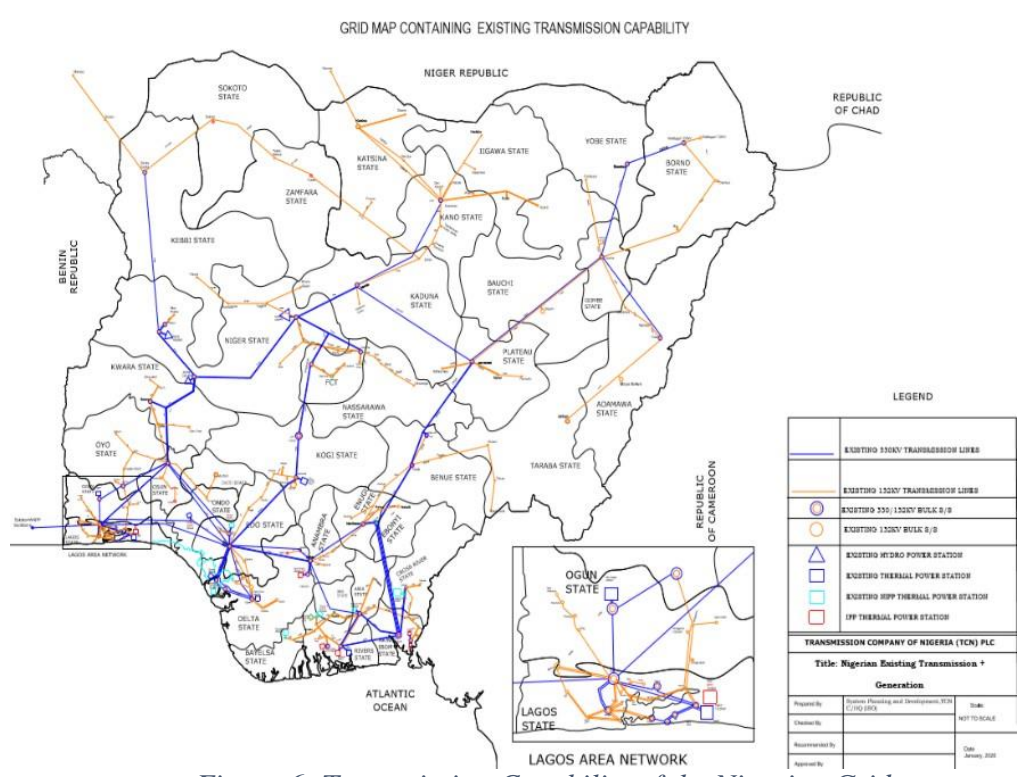

Figure 6: Transmission Capability of the Nigerian Grid
D. Challenges as regards the DISCOs

- Ageing and Infrastructural decay of distribution grid networks

- Obsolete communication equipment[12]

- Voluntary or involuntary load rejection

- Insulation failure due to lightning strikes[13]

- Little or no Investments in the distribution grid networks

- $\quad$ Bad feeder pillars and overloaded transformers[14]

- Substandard distribution lines[15]

- Little or no maintenance of the distribution grid networks. Customers sometimes have to replace burnt transformers in their areas and even pay for the connection of these transformers to the distribution grid network

- Inadequate supply of electricity to consumers and poor customer relations

- Lack of regular training and low staff morale[12]

- $22 \%$ Electricity theft[11]

- Liquidity crunch challenge with poor and late remittance of funds collected (by the DISCOs) from end users to the Nigerian Bulk Electricity Trading Plc NBET[16]

- Corruption on the part of Distribution company officials who collect electricity bills[10]

- Neglect of economically poorer areas by the DISCOs and preference for customers who seem susceptible to pay their bills.

- $\quad$ Lack of meters and estimated billing of consumers despite efforts by the national assembly to criminalize estimated billing

Table 1: Generation Profile: National Statistics[9]

\begin{tabular}{|l|l|}
\hline Generation Profile : National Statistics & MW \\
\hline Peak demand forecast (Connected +Suppressed load) & $\mathbf{2 8 8 5 0}$ \\
\hline Daily Available Generation & $\mathbf{4 7 9 5 . 8}$ \\
\hline All-time peak Gen. ever attained & $\mathbf{5 8 0 1 . 6}$ \\
\hline Maximum peak generation capacity to date & $\mathbf{7 8 5 1 . 2}$ \\
\hline $\begin{array}{l}\text { The un-utilized generation capability for MONDAY } \\
\text { 19/07/2021 as at 0600Hrs due to low load demand by } \\
\text { the DISCOs }\end{array}$ & $\mathbf{7 1 8 . 7}$ \\
\hline $\begin{array}{l}\text { The un-utilized generation capability for MONDAY } \\
\text { 19/07/2021 as at 0600Hrs due to gas constraints }\end{array}$ & $\mathbf{1 7 7 9 . 1}$ \\
\hline
\end{tabular}

Table 2: Allocated load for Lagos and Abuja as at Monday 19/07/2021

\begin{tabular}{|l|l|}
\hline DISCO & ALLOCATED LOAD(MW) \\
\hline Abuja & $\mathbf{4 5 5 . 5 0}$ \\
\hline Ikeja & $\mathbf{5 4 9 . 5 5}$ \\
\hline
\end{tabular}


E. Challenges as regards the politics and policies of the power sector.

- The continuous siting of power plants far away from gas producers and the use of lengthy pipelines to transport gas to the different thermal power stations

- The overdependence on gas for the production of electricity

- Over dependence on the importation of spares parts due to lack of local factories who produce these equipments

- Privatization design of contracts which favored the selection of politically connected bidders participating in the process rather than technically competent ones[11].

- Monopolistic operation of the DISCOs in their various zones which has led to complacency and a productively inefficient market

- The non-realization of the fact that electric power is on the concurrent legislative list. And as such, the federal and state governments both have fundamental roles to play both in the regulation and funding of the power sector

- Little provisions of foreign exchange for the purchase of needed spare parts on time[17]

- Currency issues and Foreign exchange [7]

Daily Available Generation(MW) Vs. The Un-utilized Generation(MW) for Monday 19/07/2021

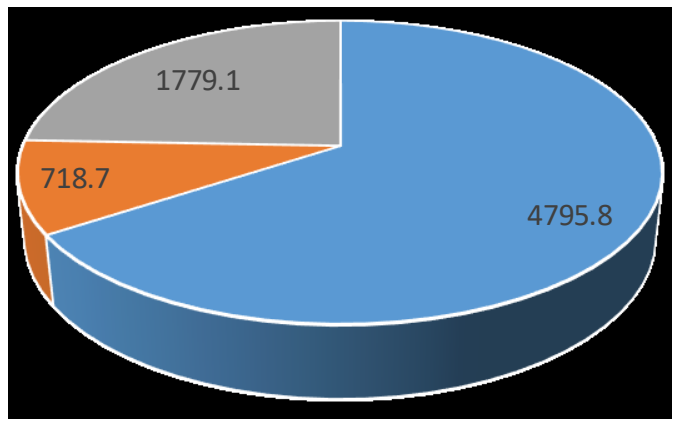

Daily Available Generation

- The un-utililized generation capability (for MONDAY $19 / 07 / 2021$ as at $0600 \mathrm{Hrs}$ due to low load demand by the DISCOs)

The un-utililized generation capability (for MONDAY $19 / 07 / 2021$ as at $0600 \mathrm{Hrs}$ due to low load demand by the DISCOs)

Figure 7: Daily Available Generation (MW) Vs. The Un-utilized Generation (MW) for Monday 19/07/2021 [9]
Table 3: Average Power Generated (MW) Vs. Installed capacity (MW)

\begin{tabular}{|c|c|c|c|}
\hline Power Station & Turbine & $\begin{array}{c}\text { Average } \\
\text { Power } \\
\text { Generated } \\
\text { MW }\end{array}$ & $\begin{array}{c}\text { Installed } \\
\text { Capacity } \\
\text { MW }\end{array}$ \\
\hline KAINJI & HYDRO & 198.08 & 800 \\
\hline JEBBA & HYDRO & 287.25 & 540 \\
\hline SHIRORO & HYDRO & 234.54 & 600 \\
\hline DADIN KOWA & HYDRO & 34.46 & 39 \\
\hline EGBIN ST1-5 & STEAM & 619.42 & 1100 \\
\hline SAPELE & STEAM & 51.02 & 720 \\
\hline SAPELE & GAS & 0.00 & 300 \\
\hline DELTA & GAS & 430.70 & 915 \\
\hline AFAM IV-V & GAS & 110.88 & 300 \\
\hline GEREGU GAS & GAS & 268.60 & 439 \\
\hline $\begin{array}{l}\text { OMOTOSHO } \\
\text { GAS }\end{array}$ & GAS & 109.13 & 336.8 \\
\hline $\begin{array}{l}\text { OLORUNSOGO } \\
\text { GAS }\end{array}$ & GAS & 119.84 & 336 \\
\hline GEREGU NIPP & GAS & 109.57 & 435 \\
\hline SAPELE NIPP & GAS & 56.46 & 500 \\
\hline ALAOJI NIPP & GAS & 194.96 & 504 \\
\hline $\begin{array}{l}\text { OLORUNSOGO } \\
\text { NIPP }\end{array}$ & GAS & 0.00 & 750 \\
\hline $\begin{array}{l}\text { OMOTOSHO } \\
\text { NIPP }\end{array}$ & GAS & 0.00 & 500 \\
\hline $\begin{array}{l}\text { ODUKPANI } \\
\text { NIPP }\end{array}$ & GAS & 198.19 & 625 \\
\hline $\begin{array}{l}\text { IHOVBOR } \\
\text { NIPP }\end{array}$ & GAS & 0.00 & 337.5 \\
\hline $\begin{array}{l}\text { GBARAIN } \\
\text { NIPP }\end{array}$ & GAS & 0.00 & 225 \\
\hline OKPAI & GAS/STEAM & 176.75 & 480 \\
\hline AZURA NIPP & GAS & 416.90 & 461 \\
\hline AFAM VI & GAS & 421.96 & 650 \\
\hline IBOM & GAS & 0.00 & 198 \\
\hline A.E.S & GAS & 0.00 & 270 \\
\hline ASC0 & GAS & 0.00 & \\
\hline OMOKU & GAS & 40.08 & 150 \\
\hline $\begin{array}{l}\text { TRANS- } \\
\text { AMADI }\end{array}$ & GAS & 74.34 & 136 \\
\hline RIVERS IPP & GAS & 0.79 & 180 \\
\hline $\begin{array}{l}\text { PARAS } \\
\text { ENERGY }\end{array}$ & GAS & 53.35 & 132 \\
\hline \multirow[t]{2}{*}{ EGBIN ST6 } & STEAM & 0.00 & 220 \\
\hline & & Total $=4207.27$ & Total $=13179.3$ \\
\hline
\end{tabular}

With the bulk price of $1 \mathrm{MWh}$ for gas power plants being NGN29,620, it therefore means that if the gas constraint problem of 19/07/2021 did last for an hour, a day, a week or a month, the NESI would have lost NGN52,696,942.00 in one hour, NGN1,264,726,608.00 in one day, NGN8,853,086,256.00 in one week or NGN37,941,798,240.00 in a month. Furthermore, the unutilized generation capability for Monday 19/07/2021 as at $0600 \mathrm{Hrs}$ (due to gas constraints and low demand by the DISCOs captured in figure 7) far out way the load allocations for Abuja Distribution Company and the IKEJA Distribution Companies as captured in table 2

\section{ROADMAP OF SOLUTIONS}

The roadmap of solutions to the numerous challenges of the Nigerian Power Sector must take into cognizance the numerous challenges of the different stakeholders of the power sector. 
A. Solutions as regards the Gas producers \& Transporter(NGC)

- Onward location of power plants at proximity to fuel resources for the following reasons:

1) To avoid the supplementary cost of building lengthy pipelines

2) To avoid the supplementary cost of maintaing the pipelines(pigging etc)

3) To avoid the supplementary cost of building pipeline pigging stations

4) To avoid the supplementary cost of pipeline compressor stations

5) To reduce drastically the risk of pipeline vandalization

6) To guarantee the delivery of dry gas

The importance of reducing the production cost of gas cannot be over emphasized as it translates into cheaper rate of bulk electricity generation, more dividends for shareholders, bonus to the staff, more profit retention which could be used for the expansion of the gas sector thereby creating employment and great industrial prospects for the economy.

\section{B. Solutions as regards the GENCOS}

- Gas contracts between the GENCOs, the gas producers and transporters would help guarantee reliable access to dry or consumer- grade natural gas and help address the problem of late payments of gas supplied to the GENCOs

- The encouragement of the DISCOs to partner with the GENCOs for onsite production and distribution of electricity as an alternate route to the grid in order to avoid stranded generation (the drop load or go down order of "X"MW by NCC as a result of TCN grid constraints)

- The encouragement of the eligible customer regime and not its reversal especially in regions where the DISCOs reject load. The reversal of the eligible customer regime could push industries to captive generation of electricity instead of returning to the status quo ante bellum of poor service delivery by the DISCOs. Culminating in a loss of revenue for the entire Nigerian Electricity Supply Industry.

- The encouragement of the West African Power Pool project with the goal of promoting and developing infrastructure for power generation and transmission. And to ensure the coordination of electric power exchanges between the member states of ECOWAS.

\section{Solutions as regards TCN}

- Investments to build new transmission lines, strengthen the existing transmission grid network and to ensure adequate coverage of the Nigerian nation. With the exponential growth of the Nigerian population, the Siemens Electricity roadmap should be one among the numerous investment projects to light up the Nigerian economy.

- Massive sensitization campaigns against the harassment of TCN officials who patrol the transmission lines during intervention or inspection schedules

- Removal of trees from transmission line paths to avoid earth faults which could cascade into system collapse.

- The use of FACTS for voltage improvement and transmission loss reduction[19]

- Massive sensitization campaigns against the willful vandalization of transmission towers

- The use of surveillance helicopters to patrol transmission lines that go through swamps and thick forests

- The swift procurement of spare parts for planned replacement of equipments 


\section{Solutions as regards the DISCOs}

- Adequate funding of distribution grid networks to build and strengthen existing networks in order to end the reign of voluntary or involuntary load rejection

- The practice of proactive and responsive maintenances strategies to ensure reliable supply of electricity to consumers. This would bring to a halt the practice of customers having to replace burnt transformers and pay for their reconnection to the distribution grid.

- The implementation of the Nigerian Electricity Regulatory Commission Electricity Theft and Other Related Regulations, 2014

- The provision of prepaid meters at affordable prices for customers to end the regime of poor and late remittance of funds collected (by the DISCOs) from end users to the Nigerian Bulk Electricity Trading

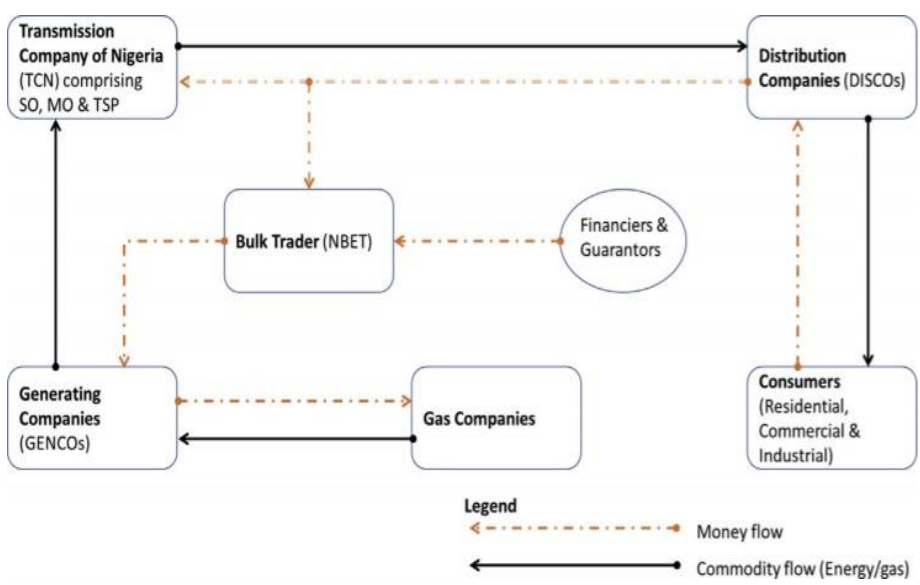

Plc NBET

Figure 9:Transitional electricity market structure of the Nigerian Electricity Supply Industry [20]

\section{E. Solutions as regards the politics and policies of the} power sector.

- The depoliticization of the activities of the power sector. Going forward, the practice of citing critical and key infrastructure based on the wimps and caprices of government officials should be disregarded and discarded beyond redemption. Power stations should be cited at proximity to fuel resources for obvious reasons. And likewise, Substations should be cited close identified load centers.

- The realization of the impact of Gas flaring on electricity growth[20] and the development of policies for the maximization of gas resources

- Proper commissioning of power plants and substations with preliminary tests on all aspects of the systems so as to identify areas of the system susceptible to fail with the goal of proffering adequate solutions to the problems.
- The diversification of resources used in the production of electricity as stipulated in the National Power System Development Master Plan[21]

- The use of Service Level Agreements to deter the DISCOs from voluntary and involuntary load rejection

- The review of the contract with the DISCOs with the goal of proffering solutions to the existing problems. The DISCOs should be ready to invest or partner with other investors to strengthen the distribution networks and perfect electricity service delivery to Nigerians.

- The procurement of only brand-new power plants and state of the art auxiliaries and not phased out equipments from developed countries.

- The promotion of local factories for the production of locally manufactured products and spare parts

- The realization of the fact that electric power is on the concurrent legislative list. And as such, the federal and state governments both have fundamental roles to play both in the regulation and funding of the power sector. It is therefore of primordial importance for the different state governments to consolidate and compliment the efforts of the federal government as regards the funding of the Nigerian Power Sector.

- $\quad$ The payment of huge and lingering electricity bills of government agencies[22]

- The encouragement of rich, illustrious and philanthropic Nigerians to either invest or finance power projects in their communities' in line with the National Power System Development Master Plan.

- The incorporation of more cogeneration technology in the Nigerian Power Sector[23] to promote energy efficiency, reduce cost and reduce GHG emission to the atmosphere

- Review of the metering contracts to companies who have done very little to solve the electricity meter deficit in Nigeria. The Meter Asset Providers and the National Mass Metering Program put in place by the government should be strengthened to meet their objective not just on paper but on the field. It would also be of tremendous help to engage more companies with licenses of no objection for metering to help in the supply of meters to the DISCOs in order to end the era of arbitrary or estimated billing.

- A reorientation of investors who engage in diesel/gasoline generator importation to Solar PV generators[24][26] to accelerate the decarbonization of the Nigerian economy and boost the rural electrification project by the Rural Electrification Agency

- The Nigerian Electricity Regulatory Commission should be unbiased in its role, effective, efficient and corruption-free, while maintaining its independence[20] 


\section{CONCLUSION}

The above present a formidable strategy and road map to solving the prevailing challenges of the Nigerian power sector, but we must remember that culture will always eat strategy for breakfast as Peter Drucker would say. And as such, developing values in tandem with the execution of the salient points mentioned above is of inestimable importance. The different stakeholders of the electricity value chain must resolve earnestly to change the tide and give reliable service delivery to Nigerians.

It is imperative to note that with abundance of human and natural resources, Nigeria has both the potential of becoming an electricity sufficient nation and the capacity of gaining foreign exchange from the sale of electricity to other African countries. However, this would only be a reality if adequate policies, regulations and funding are put in place as regards all the stakeholders bearing in mind their individual challenges.

\section{REFERENCES}

[1] "Transmission Company of Nigeria." [Online]. Available: https://www.tcn.org.ng/blog_post_sidebar110.php. [Accessed: 14-Aug-2021]

[2] "Nigeria Overview." [Online]. Available: https://www.worldbank.org/en/country/nigeria/overview. [Accessed: 14-Aug-2021].

[3] KPMG, "A Guide to the Nigerian Power Sector," no. September, pp. 1-39, 2016.

[4] "Who We Are - NBET." [Online]. Available: https://nbet.com.ng/about-us/who-we-are/. [Accessed: 12-Aug2021]. "Our Role." [Online]. Available: https://nerc.gov.ng/index.php/about/role. [Accessed: 14-Aug2021].

[6] I. O. Joseph, "Issues and challenges in the Privatized Power Sector in Nigeria," J. Sustain. Dev. Stud., vol. 6, no. 1, pp. 161 174, 2014.

[7] Stephen Ogunyiola, "Energy Crisis In Nigeria|Perpetual Minds," 2011.

[8] O. B. Adewuyi, M. K. Kiptoo, A. F. Afolayan, T. Amara, O. I. Alawode, and T. Senjyu, "Challenges and prospects of Nigeria's sustainable energy transition with lessons from other countries" experiences," Energy Reports, vol. 6, pp. 993-1009, 2020, doi: 10.1016/j.egyr.2020.04.022

[9] TCN-NCC, "Daily Operational report," Niger. Electr. Syst. Oper., 2021.

[10] A. H. Sule, "Major Factors affecting electricity generation, transmission, and distribution in Nigeria," Int. J. Eng. Math. Intell., vol. 1, no. $1 \& 3$, pp. 159-164, 2010

[11] P. Roy, K. C. Iwuamadi, and J. Ibrahim, "Breaking the cycle of corruption in Nigeria's electricity sector: a political settlements analysis," ACE SOAS Consort., vol. 020, pp. 1-19, 2020.

[12] A. S. Sambo, B. Garba, I. H. Zarma, and M. M. Gaji, "Electricity generation and the present challenges in the Nigerian power sector.," ... Energy Power ..., pp. 1-17, 2012.

[13] C. A. Awosope, Nigeria Electricity Industry : Issues, Challenges and Solutions, vol. 3, no. 2. 2014

[14] H. O. E. and T. O. E. U.P. Onochie, "The Nigeria Electric Power Sector (Opportunities and Challenges)," J. Multidiscip. Eng. Sci. Technol., vol. 2, no. 4, pp. 494-502, 2015.

[15] E. State, D. U. Onyishi, and O. Ejofodomi, "The effect of transmission and distribution losses on daily electricity supply in," vol. 2, no. 1, pp. 60-68, 2021, doi: 10.47524/tjst.21.8.

[16] PWC, "Solving the Liquidity Crunch in the Nigerian Power Sector4," 2019
Date : A Review .,” Int. J. Adv. Found. Res. Sci. Eng., vol. 1, no. 5, pp. 20-33, 2014

[18] G. Secretariat, "Operation Manual for WAPP Interconnected Power System."

[19] A. Zoppi et al., "C Urrent T Herapeutic R Esearch,” vol. 60, no. 3, pp. 26-41, 1999 .

[20] O. Adekomaya, T. Jamiru, R. Sadiku, Z. Huan, and M. Sulaiman, "Gas flaring and its impact on electricity generation in Nigeria," J. Nat. Gas Sci. Eng., vol. 29, pp. 1-6, 2016, doi: 10.1016/j.jngse.2015.12.042.

[21] F. Ministry, T. Company, and T. F. Republic, "the Project for Master Plan Study on National Power System Development in the Federal Republic of Nigeria Development in," no. February, 2019.

[22] K. Oladipo, A. A. Felix, O. Bango, O. Chukwuemeka, and F. Olawale, "Power Sector Reform in Nigeria: Challenges and Solutions," IOP Conf. Ser. Mater. Sci. Eng., vol. 413, no. 1, pp. 1-13, 2018, doi: 10.1088/1757-899X/413/1/012037.

[23] O. P. Oshevire and F. O. Odiase, "Challenges of Incorporating Co-Generation Technology in Nigeria Power System," vol. 2, no. 4, 2013.

[24] E. A. Obar, A. Touati, and N. Rabbah, "Embedded Generation Using Shared Solar," vol. 01026, pp. 1-7, 2021. 
